\title{
Tourism development, entrepreneurship and women's empowerment - Focus on Serbian countryside
}

\author{
Darko B. Vukovic, Marko Petrovic, Moinak Maiti and Aleksandra Vujko
}

\begin{abstract}
Purpose - The starting premise of this study is that women's empowerment is the goal for self-realization and that the support that comes from local tourism stakeholders represents an adequate base. In many rural areas, women have established self-help groups (SHGs), which facilitate the interaction with a wide range of stakeholders. The objective of this paper is to investigate the effects of SHGs on female entrepreneurship and self-employment in tourism.

Design/methodology/approach - To examine the research question, this study adopted a quantitative research that included a sample of 513 women in a less-advanced rural area in Serbia. For the data analysis, the generalized linear regression model (GLM) was used.

Findings - According to the results, self-employment is the leading goal of women's empowerment.

Research limitations/implications - The main limitation in the research and the authors' suggestion for future research is to increase the sample size of female respondents, so examination of their attitudes and role in the travel business in their local settings might reach higher significance. The second issue that the authors would like to point out is a highly local character of our study, so the future research should involve other rural areas in the country and from abroad (e.g. similar undeveloped countryside with noticeable, active women's role in local entrepreneurship).

Practical implications - The most important practical implications of this paper are twofold: (1) the results of the research have shown that the tourist potential of rural areas can be enhanced through local tourism stakeholders' support; (2) women without professional interest or jobs in rural areas, especially in the areas where the population is traditionally dominated by men (husband/brother/father), have a chance to earn and to be economically more independent. This research can affect future studies to investigate other aspects of empowerment depending on the difference of regions, from one side, and also alternative opportunities for tourism and local development in less-advanced rural areas, from another side.

Originality/value - The study analyzes the tourism potential of the rural areas (which are less advanced and mostly very poor in developing countries, such as Serbia). In this case, there are opportunities to increase employment, social inclusion of women, development of new tourism strategies, implementation of destination marketing, etc. Moreover, it contributes to future research in the field of stakeholders in tourism strategies.
\end{abstract}

Keywords Women's entrepreneurship, Rural settings, Local partners, Self-help groups, GLM model

Paper type Research paper

\section{Introduction}

Social structures and value systems of a society serve as a cornerstone for the similarity or dissimilarity between women and men (related to the body function of living things) and give rise to the sets of preferred and acceptable behavioral norms. Social forms such as conventions, laws, rules and social norms, as well as economic indicators, shape different behavioral patterns which consequently engender the differences between men and women and thus determine the range of rights and powers which certain groups have (Vujko et al., 2019). Women's power relies on financial assets (Soroushmehr et al. , 2012) and such an act of giving them more control over their
(Information about the authors can be found at the end of this article.)

Received 11 October 2020 Revised 22 February 2021 7 June 2021

Accepted 24 June 2021

(C) Darko B. Vukovic, Marko Petrovic, Moinak Maiti and Aleksandra Vujko. Published in Journal of Tourism Futures.

Published by Emerald Publishing Limited. This article is published under the Creative Commons Attribution (CC BY 4.0) licence. Anyone may reproduce, distribute, translate and create derivative works of this article (for both commercial and noncommercial purposes), subject to full attribution to the original publication and authors. The full terms of this licence may be seen at http://creativecommons.org/ licences/by/4.0/legalcode

Funding: This paper has been supported by the RUDN University Strategic Academic Leadership Program.

Data Availability Statement: The data that support the findings of this study are available from the corresponding author upon reasonable request.

Declaration of conflicting interests: The authors declare that they have no known competing financial interests or personal relationships which have, or could be perceived to have, influenced the work reported in this article. 
own life or situation they are in is known as women's empowerment ("WE" in further text). According to Agarwal (1997), WE in terms of changing their consciousness (from the dependent members of a society to the empowered ones) is one of many central topics related to the changes in power division in almost all the nations around the globe.

In essence, WE is the method through which women singly and jointly become well-informed and goal-oriented actors who take or support initiatives to overpower gender imparity (Rao, 2011; Cole, 2018). WE refers to a method to realize gender equality (Floro, 1995; Sudhakar Reddy et al., 2003) and as a method of awakening, WE is very strongly reflected through self-help groups (SHGs). SHGs have enabled women to achieve greater control over the resources, for instance, holding intellectual resources such as information, data, ideas and higher self-knowledge at home, in a community, society and nation (Hashemi et al., 1996; Orser et al., 2006). WE is one of the vital issues in the progression and improvement of developing societies all over the world. As the women's social position, both as individuals and as a part of a group is significantly enhanced, women's self-employment can become a political force that challenges and transforms the existing power structure. Being members of a group offers women the "visibility" and provide them with the necessary tools to do something concrete (Soroushmehr et al., 2012). Such SHGs necessitate being in close contact with a wide array of stakeholders.

The strong link between the role played by local tourism stakeholders and WE in tourism has been reported in many regions, such as Iran (Soroushmehr et al., 2012), Tanzania (Mrema, 2015), Malaysia (Kunjurman and Hussin, 2016), or in wider context such as "the third world" countries (Scheyvens, 2000) or European states (Nassani et al., 2019). All these examples have unequivocally shown that a strategic relationship with local stakeholders is necessary for WE in the tourism business, especially in rural areas. Timothy (2007) stressed the importance of connections between local stakeholder and their impact to generate possible equalities or inequalities among women and men in the local community. Moreover, in traditional societies, this is especially a result of conventions of power, which are commonly patriarchal and focus on the male figure. According to Cornwall (2003), this consequently results in the situation that many local women have been forced to quit the job or even to divorce as a result of their increased authority and participation in local decision-making. The outcome of connecting WE and women initiatives in tourism reflects on the development of our knowledge of their role in entrepreneurship as a business in the traditional sense to the notion of social innovation and change (Peeters and Ateljevic, 2009).

The unfavorable economic conditions, which are closely related to the trends of delayed and difficult transition in Serbia, as well as the last global economic crisis that occurred a decade ago, presented an aggravating circumstance for women's entrepreneurship. In addition to that, there are also significant gender inequalities which act as problems when entering entrepreneurship and later, in management and business development. Involving different stakeholders in the development of tourism destinations is significant with both practical and applicative points (including entrepreneurship, policymaking, social groups influence, etc., as indicated by Kline et al., 2018), but also in scientific debates and inclusive tourism development (Scheyvens and Biddulph, 2018). In this regard, this study can contribute in the several ways. First, it analyzes the tourism potential of the rural areas (which are less-advanced and mostly poor in developing countries, such as Serbia). In this case, there are opportunities to increase employment, social inclusion of women, development of new tourism strategies, implementation of destination marketing, etc. Second, it contributes to future research in the field of stakeholders in tourism strategies. For example, in the work by Waligo et al. (2015), in the case of ignoring stakeholder involvement, management and adhoc involvement will probably lead to failure.

Considering these outcomes, the study has the goal to explore the influence of the SHGs on female entrepreneurship and self-employment in the job positions in tourism in Serbian rural (lessadvanced) region. Considering that women have established successful SHGs in the examined areas, the research aims to investigate the effects of these SHGs on female entrepreneurship and self-employment in the travel business. By analyzing different destinations and their stakeholders, we can improve the knowledge in the following research questions:

PAGE 2 | JOURNAL OF TOURISM FUTURES $\mid$ VOL. AHEAD-OF-PRINT NO. AHEAD-OF-PRINT 2021 
1. How do stakeholders behave in different tourist destinations?

2. How successful are their strategies?

By answering these questions, this attempts to investigate WE that affects the economic development of rural destinations through the development of tourism and self-employment. In the remainder of this paper, we review in Section 2 different opinions relating to WE, woman entrepreneurship and their involvement in tourism businesses. The same section provides a background argument for hypotheses development, as well as theoretical support for the research in the case of Serbia. In Section 3, we explain the sample and study area, research procedure and the methodology applied for data analysis. The results and explanations for accepting the tested hypotheses are presented in Section 4. Section 5 presents discussion and results related to secondary sources. Section 6 provides concluding remarks with additional explanations of the implications and the limitations of this study.

\section{Theoretical background}

\subsection{Literature review}

Women's entrepreneurship is found as an opportunity for economic empowerment. Involvement of women in entrepreneurship is strongly connected with improving the status of women, family and community well-being (Haugh and Talwar, 2016; Scott et al., 2012; Ardrey et al., 2006; Jamali, 2009). According to Haugh and Talwar (2016), Clarke and Holt (2010), there are differences in conventional and social entrepreneurship. Conventional entrepreneurship refers to innovations, new business venturing and models as strong commercial objectives. On the other side, social entrepreneurship is more ethical in entrepreneurial activity, with a precise social change outline, influenced by social and environmental values (Haugh and Talwar, 2016; Branzei, 2012). The relationship between women entrepreneurship and social entrepreneurship was discussed by Haugh and Talwar (2016), Rindova et al. (2009) and Steyaert (2007), where these authors researched the main connection between women's entrepreneurship, empowerment and social change. They found strong connection for these issues. Women's entrepreneurship is a multidimensional phenomenon (De Bruin et al. , 2006) which can be viewed from several perspectives: as women's activism when women invest in women and move them to action (Calás et al., 2009); as an economic development, from the aspect of investing in business (Heilman and Chen, 2003; Hania et al. , 2012); as a way of social policy when a sense of security in the material meaning affects the encouragement for self-employment (Godwyn, 2009; Kimbu and Ngoasong, 2016); and as sustainable development, when women's entrepreneurship can be seen as a way to harmonize economic development with environmental and social development, through socially responsible business (Markantoni and van Hoven, 2012; Shams, 2017).

The importance of the involvement of various types of stakeholders in tourism sector is increasingly receiving more attention (Shams, 2016) and stakeholders in tourism are defined as "any cluster or individual who will have an effect on tourism development" (Byrd, 2007, p. 6). Their role in the system of women's entrepreneurship and self-employment has reflected as "an example of good practice" analysis, and usually is a backbone for WE (Buhalis, 2000; Dredge, 1999). However, most of these studies reflect US- and Euro-centric bias. Some other studies (e.g. Cinar, 2001; Al-Dajani, 2007; Al-Dajani and Marlow, 2013) analyzed the interface between entrepreneurial activities, gender, migrant status and empowerment. In comparison with US- and Euro-centric bias, these studies have issues of displaced and marginalized women, with large material, cultural and economic deprivation. Such papers illustrated the role of displaced women and their entrepreneurial capacities in creating social change. On the other side, in US- and Euro-centric studies, women have greater stakeholders' support in entrepreneurship. One of the most common aspects of such women's entrepreneurship is in the field of tourism. Besides being a good practice in entrepreneurship, with stakeholders' support (Cooper et al. , 2009; Gossling et al. , 2009; Waligo et al., 2015), this practice has also shown a strong impact on WE (Datta and Gailey, 2012; Scheyvens and Biddulph, 2018). 
According to the World Tourism Organization (2011), tourism work is proposed as the best way to promote WE considering that it presents a wide range of income-generation opportunities for women. Baikuntha and Elizabeth (2013) found in their research that home stay tourism is a very popular way for women's self-employment in many destinations. Moreover, this type of entrepreneurship is very important for destinations which cannot make extensive infrastructural investments. Their study was based on semi-structured interviews methodology whose results showed that women's tourism entrepreneurship is very important for WE and sustainable community development. A similar study was previously considered in the work by Ateljevic (2009) who examined entrepreneurial behavior of small tourism businesses and their influence on the regional development. The same author used in-depth interviews and a questionnaire to study entrepreneurial behavior of small business in tourism. In the research of Tajeddini et al. (2017), women were influenced by environmental factors in entrepreneurial tourism. Authors (Tajeddini et al., 2017) used interviews to analyze how women used limited resources and financial capital to succeed in tourism industry. Bensemann and Hall (2010) found that women are in cooperative relationships in rural tourism businesses. They used in-depth interviews to analyze women's experiences in rural tourism accommodation business. According to their results, women are running their businesses as a "hobby" and these businesses are mostly motivated and influenced by non-economic factor, personal preferences and their lifestyles. Their findings are very important in the promotion of gender equality and the inclusion of women in the entrepreneurial process. Ferguson (2011) dealt with a similar issue. However, this author was focused on the third Millennium Development Goal of gender equality and WE. According to her results, WE depends strongly of substantive reframing of Millennium Development Goal policies.

Over the past 20 years, the trend of WE has evolved and there is a growing interest in this topic (Kabeer, 2005; Narayan, 2002; Vujko et al., 2019). Special attention has been paid to the psychological dimension of the empowerment (Osirim, 2001). According to the same author, it is evident that women's sense of identity and self-perception is one of the most vital factors. Moreover, it has been suggested that a sense of social belonging, self-esteem, autonomy, as well as the endeavor for attaining economic independence, all outline WE. Kabeer (2005) stated that there are three dimensions of WE: (1) access to resources, as well as preconditions which are necessary for obtaining them; (2) agency, as well as the process of acquiring knowledge; and (3) achievements, as well as the outcomes. Moser (1989) defined WE as "giving women the right to make decisions" (Soroushmehr et al., 2012). According to Seguino (2000), WE is a tool to take control over their lives and overcome the obstacles posed by traditional patriarchal ideology (Batliwala, 1994). Schuler and Hashemi (1993) articulated that the dimensions of WE include: internal energy and the vision of the future, quality, as well as economic independence. There is general agreement that empowerment may be a method that is manifested in more than one dimension. The foremost known dimension is women's awareness and education (Presser and Sen, 2003). It can be articulated that WE typically begin with an effort to know how and why women need to be empowered (Datta and Gailey, 2012).

\subsection{Hypothesis development}

The early studies explored self-employment as one of the main goals of WE. In the case of India, Thangamani and Muthuselvi (2013) identify women empowerment through SHG and change of socioeconomic factor after joining women to SHG. The authors used the interview schedule method for their research. The results of their analysis showed a strong positive relationship between joining SHG, self-employment and WE in rural areas. In a recent study, Neetha (2020) confirmed that the formation of SHG in India was seen as an important step to help women in self-employment, especially in environments where there is great gender inequality. Women who joined SHG progressed faster in self-employment and in raising their standard of living. In the study of Rinaldi and Salerno (2019), tourism offers incredible opportunities for gender equality. These authors studied Himachal Pradesh, the rural area in India to analyze the contribution of the rural tourism sector in women's self-employment, the labor market availability, WE and growing impact generation 
capacity. They find that the tourism sector is an important contributor to the previously mentioned goals. The same results were obtained from the study of Anand et al. (2020) from their robust study of 6,000 participants of the SHG program in Uttar Pradesh. These authors (2020) used the survey to analyze the utility of self-helped groups on WE, self-employment and quality of life. According to their results, these indicators are strongly related to the support of SHG in mostly rural areas.

In the studies relating to the case of the other regions, a similar methodology was applied with the findings that support the relationship between WE, employment in tourism and female entrepreneurship. Tajeddini et al. (2017) used in-depth interviews in the case of Bali (Indonesia) to study how women were influenced by environmental factors (their culture and heritage) to use entrepreneurial characteristics in tourism. According to their results, women in Bali are closely related to their families, with the strong feelings to care for others, and in most cases, their entrepreneurship is seen as additional work (because they spend most of their time managing the house and taking care of the family members). The largest market orientation of these women is in the tourism sector. Firstly, while unmarried, they work in hotels and restaurants, and after marriage, they start a small business. The same authors recognized that one of the key conditions for starting a business is the availability of the initial capital. In studies prior to this, Heilman and Chen (2003) and Bensemann and Hall (2010) observed similar motives of women to start businesses in rural areas. The key factors for starting a business for women in rural areas are the initial capital and the family support. Even more, Nassani et al. (2019) focused their study on international tourism, WE and financial intermediaries in a panel of 24 selected European countries. The authors used the panel fixed effect regression model to analyze the role of financial intermediaries on WE in tourism. Among their confirmed study hypotheses was the hypothesis that finance led to women's empowerment.

Ateljevic (2009) also notes the importance of small business in tourism of rural areas. He conducted in-depth interviews and survey in the Wairarapa region near Wellington, New Zealand, to analyze the entrepreneurial behavior of small businesses in tourism in rural areas. According to this study, there are differences in urban and rural area business environments. He used the bottom-up model (which also includes regional development) to find the relationship between rising small tourism businesses and business environment in rural areas. Bensemann and Hall (2010) note that in New Zealand motives for tourism in rural areas are mostly characterized by lifestyles and "hobby" as non-economic motivation. Authors collected 109 in-depth interviews with women in copreneurial business relationships to analyze different indicators of partnership (with their husbands) in running small businesses (accommodation businesses) in rural touristic areas. These social indicators are related to care for others, freedom, gender equality and personal feelings of women. Finally, previously mentioned studies from New Zealand cases, have shown different motives in women rural tourism entrepreneurship, greater support of the business environment, freedom, and greater gender equality compared with the studies in India, Indonesia and other studies from developing countries.

According to the discussed literature, our research starts from the main hypothesis HO: Selfemployment is the final goal of WE. Also, three low-level hypotheses were formed: $\mathrm{H} 1$ - Women's empowerment depends on the motive "care for others"; $\mathrm{H} 2$ - Women's empowerment depends on the initial capital as part of the business environment; and H3 - Women's empowerment depends on the support of SHGs.

\subsection{The Serbian context}

The study was conducted in Serbia where rural society is one of the most traditional and patriarchal ones in Europe (Jarić, 2006; Kolin and Čičkarić, 2010) and women still have a lot of social issues, facing many restrictions such as employability barriers, inequality in salaries and insufficient financial independence. This situation is a common problem in many other developing nonwestern countries (Ramanathan, 2004). In such a situation, entrepreneurship and selfemployment could significantly empower women because it helps them to achieve "the ability to take action" (Calás et al., 2009; Datta and Gailey, 2012). Women's organized entrepreneurship in 
Serbia was first mentioned in the first half of the 1990s, as the social inclusion of women refugees from the war-affected areas in the neighboring Bosnia and Herzegovina, and Croatia. Various educational workshops were organized to boost their awareness concerning start-ups, primarily as sole traders and workshops owners so that they may become self-dependent.

The transition in Serbia, especially in terms of political, financial and social aspects, starting from the 2000s, marks the beginning of a new epoch of the progress of female actions in non-urban settings (Vukovic et al., 2019). This process involved the local entrepreneurship and connection with various economic activities, including rural tourism (Demirovic et al., 2017). Since then, the number of women's enterprises has remarkably grown, and the structure has changed, so nowadays the involvement of female workers has become common in numerous service businesses, e.g. communication technologies, bookkeeping, intelligence services and especially in travel business (Vujko et al., 2019). In addition, the rural areas in Serbia that were mostly neglected, economically and socially, have become a significant part of this new advancement on the national level. We opted for the selected villages because we wanted to explore the level of women's involvement in local tourismrelated activities. This type of area is traditionally characterized by a high impact of men's economic dominance and old style values so the role of women in the local economy has been neglected for centuries. Together with this, Petrović et al. (2017) underlined the fact that there is a small number of similar initiatives in the Serbian countryside, and the selected area represents one of the most active.

Even more, Serbia has been chosen as a representative European developing country that is still in the process of social inclusion of women in modern economic flows, especially in the countryside. Furthermore, the selected part of Serbia (Srem District) is one of the main initiators of this process (Vujko et al., 2019), which makes it even more illustrative for this type of research. With the goal to explore the influence of the SHGs on female entrepreneurship and self-employment in the job positions in tourism, it was highly challenging to conduct this type of research and to present inventing findings.

\section{Research methodology}

\subsection{Study area, and sample}

The analysis of this paper should point to the significance of the role of women's involvement in the local economic activities. The study area involves 25 village settlements with women's dynamic participation in the local economy (see Plate 1). This area includes the surroundings of Fruška Gora Mountain located in the Srem District, in the northern part of Serbia. The area has a special predisposition for the development of rural tourism due to an advantaged geographical position, such as the proximity of two international highways ( $E-70$ and $E-75)$, the two largest urban centers in Serbia-Belgrade and Novi Sad, and the international airport "Nikola Tesla" near Belgrade (Vujko et al., 2018; Petrović et al., 2018).

The first step in the research regarded the socio-demographic characteristics of the sample $(N=513)$. The respondents are of different ages, educational levels, marital statuses, and monthly income. The largest percentage of women, 39.4\% (202), was from the age group from 26 to 35 , followed by $30.5 \%$ (156) who were over 56 years of age, followed by the ones aged from 46 to 55 with $17.9 \%$ (92), then the participants aged from 36 to 45 with $9.9 \%$ (51), and the lowest percentage represented the participants aged from 16 to 25 with 2.3\% (12). These data suggest that the respondents in the older age category (above 56 years) and younger ones (26-35 years) contribute with more than $50 \%$ in the sample. The possible reasons could be that women choose education over a job at a younger age and the women from other age groups like the involvement related to the sources of income. In addition, the majority of respondents are with a regular monthly income from 251 to 400 Euros (with nearly $73 \%$ of all the respondents), which also presents the national, average income ranges for the same time frame. More details on the sample structure are given in Table 1.

SHGs were formed mainly in the period from 2000 to 2017, with the main goal of the local WE. Their members are mostly involved in the field of culture and handicrafts (see some examples in Table 2),

PAGE 6 JOURNAL OF TOURISM FUTURES $\mid$ VOL. AHEAD-OF-PRINT NO. AHEAD-OF-PRINT 2021 


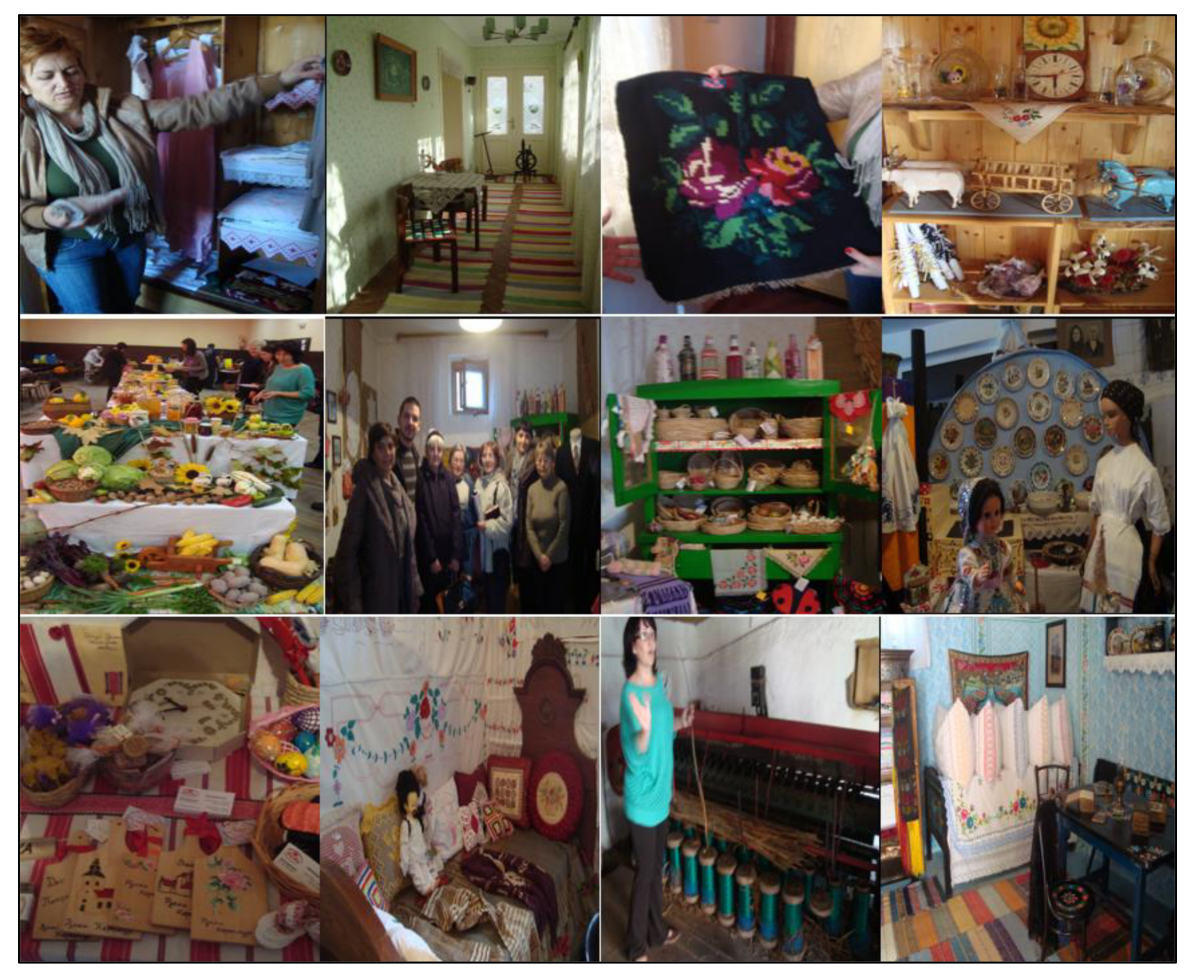

Source(s): Authors, 2013-2019

and their participation at fairs and other local events connects them with each other and with other interested stakeholders.

\subsection{Research procedure and design}

A questionnaire-based survey is applied to investigate women's experiences in the rural tourism accommodation business. The direct examination of the target groups was done using an "inperson" technique, where all the respondents had access to questionnaires. However, due to the specific circumstances (e.g. the incomprehensibility of certain questions, a large number of respondents, promptness of data entry), the questionnaires were filled out by the team of interviewers (co-authors of the paper with accompanying assistants) on respondents' behalf and with their consent. In other words, respondents were asked to verbally respond to questions from the questionnaire and after giving their answer, it was recorded on their behalf by interviewers. The study aimed to collect quantitative data, but additionally, to identify motives, complications, and conditions stimulating their opinions/attitudes as well (which can be classified as an interpretive aspect). In this respect, this study can be classified as quantitative (by using the questionnaire) with a qualitative/verbal approach (through interviews with the selected respondents). Concerning specific conditions, related approaches have been recorded in earlier reports (e.g. Decrop, 2004; Phillimore and Goodson, 2004; Veal, 2017).

The gathering of data was performed on the selected locations on many occasions from 2013 to 2019. The research was undertaken with the female respondents who showed interest in participating in the study. The only conditions were that they were the members of local associations and that their domicile address was in the researched villages. The examination of the target groups was done using a face-to-face technique. In the beginning, the respondents were 
Table 1 Socio-demographic characteristics of the respondents (\%)

Age

$16-25$ years

Education

Elementary/Middle school $\quad 12.8$

High school

\section{Marital status}

Married

77.2

Single

Divorced

Parent/No children

Parent

Monthly income (in Euros)

Source(s): Research of the authors

informed about the subject of the research. All relevant statements were written down in the Serbian language, in order to stay as original statements and permit adequate analysis, with minimal loss of information. In addition, all the data were transcribed, translated into English, and proceed to analysis, including the systematization and categorization of discourses, with the aim to identify the key issues of each examinees' statements, as well as to allow the patterns identification. The procedure for the examination was elaborated based on the theoretical background, covering the main factors that influence WE through female entrepreneurship and self-employment.

The population for this study consists of 513 women, as randomly chosen members of 32 totally different SHGs, from 25 rural settlements in the examined region. Of the 600 distributed questionnaires in total, 513 were filled fully and correctly and used in the upcoming statistical procedure. The number represents $85.5 \%$ of the response rate, which is considered a proper indicator of the measurement scale acceptance (Babbie, 1986). According to Bagozzi (1981), the sample size in the study $(N \geq 51)$ is sufficient for consequential statistical assessments for this type of research. Moreover, the sample size is in accordance with Hair et al.'s (2006) suggestion regarding the minimum sample size.

In this respect, the sample in this research $(N=513)$ may be considered more than adequate for meaningful assessments. Correspondingly, quantitative method was selected for the gathering and the examination of the presented data. The decision is also based on the exploratory nature of the research, the key goal of which is a better understanding of the role of SHGs in WE in order to complement the literature review undertaken.

In order to test the hypothesis and low-level hypotheses, the research was conducted based on the models previously tested by Ateljevic (2009), Baikuntha and Elizabeth (2013) and Tajeddini et al. (2017). Considering that the study investigates the effect of SHGs on two important dimensions female entrepreneurship and self-employment, the research objective relies on the relations between 
Table 2 Examples of some women's stakeholders in the study area

\begin{tabular}{|c|c|c|}
\hline Name & Place & Description of the activities \\
\hline Vera Žigić & Rakovac & Icon paintings on mushrooms \\
\hline Women's Association "Mountain Rose" & Rakovac & $\begin{array}{l}\text { Founded on January } 16,2009 \text {. Its aim is to } \\
\text { promote women's art, old art and cultural } \\
\text { tradition of the region in which they live. } \\
\text { Charity work and making souvenirs are also } \\
\text { recognized when it comes to this association }\end{array}$ \\
\hline Branka Jukić & Beočin & Iconographer (Byzantine icon painting) \\
\hline $\begin{array}{l}\text { The Association of Women "Danubian } \\
\text { Flower" }\end{array}$ & Beočin & $\begin{array}{l}\text { Traditional techniques of embroidery and } \\
\text { making gold embroidery }\end{array}$ \\
\hline Beekeeping "Bikar" & $\begin{array}{l}\text { Sremski } \\
\text { Karlovci }\end{array}$ & $\begin{array}{l}\text { The family company "Beekeeping Bikar" } \\
\text { offers various kinds of honey and apiculture } \\
\text { products. Available to everyone are linden, } \\
\text { acacia, meadow and many other kinds of } \\
\text { honey. Besides these, they offer wine, } \\
\text { honey, vinegar, and numerous body care } \\
\text { products made from bee products }\end{array}$ \\
\hline Non-governmental Organizations: & Sremski & Non-governmental organizations mainly \\
\hline $\begin{array}{l}\text { Association for the Reconstruction and } \\
\text { Development of Sremski Karlovci }\end{array}$ & Karlovci & $\begin{array}{l}\text { gather women from Sremski Karlovci and } \\
\text { have been active in projects in the field of } \\
\text { environment protection, promotion of } \\
\text { women's rights and traditional crafts of } \\
\text { Sremski Karlovci. Today, the organizations } \\
\text { intend to promote the old methods of } \\
\text { producing garments made of wool using the } \\
\text { so-called "pustovanje" technique }\end{array}$ \\
\hline The Association of Women "Karlowitz Ltd." & $\begin{array}{l}\text { Sremski } \\
\text { Karlovci }\end{array}$ & $\begin{array}{l}\text { The offer of this association includes a lot of } \\
\text { interesting things. Certainly, the most } \\
\text { famous is the German traditional cake } \\
\text { "kuglof" to which various spices, wine, fruit, } \\
\text { etc. are added }\end{array}$ \\
\hline Koviljka Živanov & $\begin{array}{l}\text { Sremski } \\
\text { Karlovci }\end{array}$ & Creating embroidered handicrafts \\
\hline Zorica Avramović & Rivica & $\begin{array}{l}\text { Production of specific types of cheese and } \\
\text { dairy products }\end{array}$ \\
\hline Draginja Budimčić & Irig & $\begin{array}{l}\text { Souvenirs such as fridge magnets in the } \\
\text { shape of the relief of Irig, knit bubble of } \\
\text { gypsum (wine), vineyard keeper etc. }\end{array}$ \\
\hline Vera Mulaji & Irig & $\begin{array}{l}\text { Production of various types of homemade } \\
\text { cakes }\end{array}$ \\
\hline
\end{tabular}

them. In other words, the study will attempt to shed more light on the main factors that influence WE through these dimensions. The analysis will reveal that the main causes that influence WE are the motives, the business surroundings, and the impact of SHGs in their local setting.

An exploratory approach to the women's answers was used to help define the meaning of "empowerment" in Serbia. Through the research process and documents analysis, we sought to better understand how the women felt about their own empowerment. These empowerment scores and dimensions scores have been used for further analysis. After the analysis, inferences related to WE, the relationship between variables and the role of SHGs in WE have been made.

\subsection{Data analysis}

We applied the generalized linear regression model (GLM) to explore the women's attitudes in the selected villages. The model was presented by Nelder and Vedderburn (1972), and quickly becomes important tool for efficient statistical analysis. The quantitative data were processed with the statistical program SPSS 21.0. GLM regression defines how several variables affect other 
variables with the basically three features: a random component, a linear predictor, and link function. A random component identifies the conditional distribution of the response variable $\left(Y_{i}\right)$ according to the values of the explanatory model variables. A linear predictor is linear model or linear function regressor (in our function $X_{i}$ ) which includes independent variables (transformations to quantitative explanatory variables) in our model. Link function converts the expectation of the variable $Y_{i}$ to the linear function predictor $X_{i}$. The advantage of this model is in the evaluation of asymptotic standard errors of the coefficients. Asymptotic standard errors are like statistical standard errors based upon some mathematical simplification. In the process of regression of coefficients, GLM uses the maximum likelihood method (statistical model which provides the most probable observed data) and quasi likelihood method (a model that allows overdispersion - for example, data that have far greater variability than would be estimated from the statistical model). Moreover, GLM regressions have a special advantage over ordinary least squares (OLS) regression so that it can be used even if the obtained data do not follow normal distribution (a situation in which the distribution of variables does not have the shape of a symmetrical bell; this means that there are extreme values that deviate far from the mean). The present study used the following GLM regression model as shown below:

$$
Y_{i}=\beta 0+\beta 1 X 1_{i}+\ldots+\beta p X 10_{i}+e_{i}
$$

where

$Y_{\mathrm{i}}=$ Dependable variable and

$X 1$ to $X 10$ are all independent variables

$e=$ error terms.

In this study GLM is applied for the robustness checking, to examine whether the independent variables (from questionnaire) generally influence the women's entrepreneurship and selfemployment (presented by the factor scores). An exploratory factor analysis was used to generate independent variables toward women's entrepreneurship and self-employment. A confirmatory procedure is also used to examine the interrelationships in the measure. We use deductive analyses to obtain numerical properties of a population and assigning probabilities to these predictions. The generalized linear regression method was used to calculate each factor score (in Table 4 AGE, AREA, CHD, EDU, EMP, FAM, MOT, SHG, STR). According to these GLM scores (set as dependent variables), the study tests the effect of independent variables on women's entrepreneurship and self-employment. Hypotheses are confirmed or rejected according to the result of the regression value and significance ( $\alpha$ regression value and $p$ significance). Relative to validity of regression values, the analysis of this study shows how much indicators (independent variables) influence the defined factors of women's entrepreneurship and self-employment. We have found inspiration to use GLM in hypothesis testing in several studies in the field of tourism: (1) In the study of Stumpf et al. (2020) GLM examines the relationships of how tourists' satisfaction affects their intention to return for the main holiday to the same European Union country (a sample of 30,105 responses collected by each member countries of EU). (2) Swart and Roodt (2015) use GLM to examine market segmentation variables in the prediction of business tourist retention (a sample of 498 respondents). (3) Kim et al. (2019) use GLM to examine the perception of a destination image as a stable or fluctuate phenomenon (a sample of 161 respondents). (4) Huo and Miller (2007) measure the satisfaction of small tourism sector in Samoa, using also GLM (a sample of 200 respondents).

\section{Results}

Based on the research outcomes, it has been found that women are motivated to start up their own businesses to support the families and to obtain a higher degree of independence. Most of them answered that financial constraints are low in terms of the favorable business environment in Serbia. However, most of the entrepreneurial activities of women of Fruška Gora Mountain belongs to the informal sector. For policymakers, the informal sector is an important source of employment 
in developing countries (de Groot et al., 2017; Charmes, 2012). We find that entrepreneurial activities in this study are concentrated in subsistence informality, including their own account and informality associated with small-scale entrepreneurship. According to our results, such activities refer to food and handicrafts small-scale production. An important feature in this study that recognizes the informal sector entrepreneurship is lower entry barriers. Low financial constraints are in line with the claim, due to the reason that Serbian policymakers offer various programs to encourage entrepreneurship and start-up business.

The research has shown that "care for others" is the strongest motivator when it comes to empowerment. Even women who have never been employed before and have never thought about it in the first place have been motivated to "start from scratch" and join the associations, to do something for those they care about. The results seen in Table 3 show that the strongest trigger for

Table 3 Research results presented in frequencies and percentages ( $N=513)$

Attachment 1. What was your motivation to start your own business?

Care about others (families, children, parents)

A higher degree of freedom and independence

Dissatisfaction with previous work (workplace, associates, working conditions)

Search for achievements

Something else

Attachment 2. What is your opinion about business environment in Serbia?

The problem is financial

Women have more responsibilities in the children's education

Social environment

The problem of the marginalization, humiliation of women and sexual harassment

High levels of corruption and strong male network

Attachment 3. Do you feel empowered as a member of an SHG?

Yes

No

I do not know

Attachment 4. Which stakeholders have the strongest empowerment on you and in which areas?

Traditional crafts and making handicrafts

Rural tourism

Ecology and environmental improvements

Humanitarian work and care for the local community

Food preparation

Agricultural activities

I do not know

Attachment 5. Would you start your own business and what would you do?

Souvenirs production

Rural tourism

Jewelry production

Needlework

Weaving and crocheting

Production of traditional clothing and footwear

Plants

I do not know

Attachment 6. What is the essential role of the SHG?

Providing information on loans and other financing conditions

Empowerment through networking with stakeholders

Participation in projects

Providing the documentation required to start a business

The possibility of a common selling in the market

Organization of gatherings, fairs and other events

I do not know 
Table 4 GLM regression findings

\begin{tabular}{|c|c|c|c|c|}
\hline Variable & Coefficient & Std. Error & z-Statistic & Prob \\
\hline Constant & 0.591702 & 0.046016 & 12.85863 & 0.0000 \\
\hline AGE & 0.000462 & 0.004935 & 0.093570 & 0.9255 \\
\hline AREA & 0.006847 & 0.007787 & 0.879231 & 0.3793 \\
\hline $\mathrm{CHD}$ & -0.022058 & 0.017879 & -1.233718 & 0.2173 \\
\hline EDU & -0.040061 & 0.007397 & -5.415781 & 0.0000 \\
\hline EMP & -0.094696 & 0.015040 & -6.296438 & 0.0000 \\
\hline FAM & 0.028745 & 0.008812 & 3.261876 & 0.0011 \\
\hline MOT & 0.012650 & 0.005361 & 2.359491 & 0.0183 \\
\hline SHG & -0.019862 & 0.004436 & -4.477769 & 0.0000 \\
\hline STR & 0.018391 & 0.004070 & 4.519306 & 0.0000 \\
\hline Mean dependent var & 2.187135 & \multicolumn{2}{|c|}{ S.D. Dependent var } & 0.795538 \\
\hline Sum squared resid & 267.3984 & \multicolumn{2}{|c|}{ Log likelihood } & -478.5070 \\
\hline Akaike info criterion & 1.904511 & \multicolumn{2}{|c|}{ Schwarz criterion } & 1.987167 \\
\hline Hannan-Quinn criterion & 1.936909 & \multicolumn{2}{|c|}{ Deviance } & 44.27567 \\
\hline Deviance statistic & 0.088023 & \multicolumn{2}{|c|}{ Restr. Deviance } & 55.59047 \\
\hline LR statistic & 118.6909 & \multicolumn{2}{|c|}{ Prob (LR statistic) } & 0.000000 \\
\hline Pearson SSR & 47.95099 & \multirow{2}{*}{\multicolumn{2}{|c|}{ Pearson statistic }} & 0.095330 \\
\hline Dispersion & 0.095330 & & & \\
\hline
\end{tabular}

Note(s): In terms of hypothesis testing, the following variables are significant at $5 \%$ level (with the $\alpha \leq 0,05$ ) as estimated by the GLM regressions (Table 4): Motivation (What was your motivation to set up your own enterprise?); Education; Empowerment (Do you feel empowered as a member of an SHG?); Family; SHG (What is the essential role of the SHG?); and STR (Would you start your own business and what would you do?)

starting their own business was the motive "care for others," which implies that women enter entrepreneurship and want to be empowered to be able to do something for their family (Jain and Joy, 1997), usually their children (52.4\%). The paper deals with the data related to the family status of women and their achievement as parents. The study showed that $77.2 \%$ (396) of women are in a marriage status, $11.3 \%$ (58) of women are single, 9.4\% (48) are divorced, and $2.1 \%$ (11) are widows. Then, the study showed that $83.8 \%$ (430) of women are parents, and $16.2 \%$ (83) of women have no children (Table 1). GLM regression results shown in Table 4 confirm that there exists a statistically significant relationship between the business environment and other variables such as motivation $(p=0.0183)$ and family $(p=0.0011)$. Moreover, the coefficients of both variables' motivation $(0.012650)$ and family $(0.028745)$ are positive. This means that these two variables have a direct impact on the business environment. The analysis of the data confirmed lower-level hypothesis $\mathrm{H} 1$ Women's empowerment depends on motive "care for others." In our study, "care for others" is an important feature of social entrepreneurship. This characteristic is typical for social entrepreneurship (according to Haugh and Talwar, 2016; and Branzei, 2012) because it is more ethical and influenced by social and environmental values. On the other hand, the strong motivation of these women (encouraged by ethical norms) indirectly affects the development of the region, higher employment, and greater empowerment. At the same time, these are the goals of policymakers, having in mind the harmonization of laws and regulations of the Republic of Serbia with the legislation of the European Union (EU) (given that Serbia is a candidate for EU membership).

Self-improvement is the next highly rated aspect of empowerment. Self-confidence strengthens self-awareness, and a strong and successful woman is free and self-sufficient. Empowerment affects women's appreciation of themselves; therefore, they can fight for themselves, their position in society and business environment. They also added that most of them feel confident or empowered by being members of SHGs. The reason could be that an SHG helps them to solve their financial constraints in terms of consultation and other helps. When they are asked about which area they would consider to start their own business in, most of them answered "traditional crafts, making handicrafts" and "rural tourism." When asked about the specific business they want to do, most of them answered "souvenir productions." Self-improvement, confidence and awareness are closely related to self-employment, which is an important feature of women social entrepreneurship, enhancing financial independence of women in Serbia. Second, this

PAGE 12 JJOURNAL OF TOURISM FUTURES $\mid$ VOL. AHEAD-OF-PRINT NO. AHEAD-OF-PRINT 2021 
characteristic is also closely related to empowerment, considering that by strengthening financial independence (through entrepreneurial activities), women achieve empowerment. In our case, SHGs played a key role in helping women to achieve these goals. Table 3 shows the factors that influence the necessity of empowerment. The first factor is the "lack of initial funds" (76.6\%). Then comes the "child care" (8.4\%). The third is the social environment (6.4\%) in terms of the lack of understanding for women entrepreneurs. Then, there is marginalization, denigration of women and sexual harassment (5.1\%). In a rigorous patriarchal system, disadvantages come from the high levels of corruption and strong male network (3.5\%). GLM regression values (with the $\alpha \leq 0,05$ ) confirm the low-level hypothesis h2 -Women's empowerment depends on the initial capital as part of the business environment.

The inclusion in self-help groups has empowered women to increase more noteworthy authority over assets like material ownership, scholarly assets like learning, data, thoughts, and basic leadership at home, SHG network, in the society and in the country. This self-improvement gathering proposes a creation of employment, for example, manual generation of painstaking work: weaving, sewing, making adornments, dolls and magnets made of mortar, drying herbs for tea, making liquor, delivering tinctures, making cakes and so on. When the activity is endorsed by the gathering, 33\% of financing sources are coordinated together; smaller-scale financing by the members themselves through a pivoting credit relationship under the authority of one of them. The outcomes found in Table 3 demonstrate that $96.9 \%$ of women feel extremely enabled as individuals from an SHG. It is quite evident that the individuals from SHGs perceive these establishments as spots where they can get sufficient data and the necessary financial support for their start-ups (41.3\%). Thus, GLM regression values (with the $\alpha \leq 0.05$ ) confirm the hypothesis H3 - Women's empowerment depends on the support of SHGs.

Next, the research has shown that women do not have enough information and they were not educated enough for starting their own businesses. In general, the largest percentage of them $70.1 \%$ (360) was with high school education, followed by $16.3 \%$ (83) with graduate degree, $12.8 \%$ (66) with elementary/middle school degree, and $0.8 \%$ (4) with postgraduate degree (Table 1). That should be the main reason of the necessity for various types of support and assistance, such as stakeholder's support, which appear in various institutions such as SHGs. According to the results in Table 4, GLM regression also estimates that the education $(p=0.0000)$ variable is statistically significant and negatively related to the business environment. These results can be explained concerning the lack of higher woman education from Fruška Gora Mountain. These women would rather engage in social entrepreneurship than formal entrepreneurship, because they do not have higher skills and entrepreneurial tools acquired at universities. Therefore, the lack of higher education is replaced with motives of self-improvement, self-employment, and care for others.

Lastly, women's entrepreneurship in this region mostly relates to handiwork and souvenir production (STR factor). The outcomes found in Table 3 demonstrate that the impact of stakeholders is the most serious in supporting old crafts and making handiwork (65.1\%). This is supported by the information from Table 2 by which $79.3 \%$ of women would start their own business in the field of handiwork and souvenir production, while $19.1 \%$ of women would be occupied with rural tourism. Here, one can point out two features in the analysis of the obtained results: (1) The influence of gender upon entrepreneurial venturing identify handiwork and souvenir production primarily a business run by women in Serbia. Such entrepreneurship indicates that women operate home-based enterprises. (2) Women's empowerment in Serbia (Fruška Gora Mountain case) is a process that changes women's orientation, reducing agricultural engagement and increasing entrepreneurial activity. This process assumes and incorporates gender and sociocultural norms, which are directly related to the empowerment of women in Serbia. This situation can be attributed to the efforts of policy makers to motivate and encourage women (through a better business environment) to concentrate to work or run their business in sectors that give them greater satisfaction and self-confidence. According to GLM regression results (Table 4), STR variable is statistically $(p=0.0000)$ significant and directly related to the business environment variable. 


\section{Discussion}

Female self-governance is regularly characterized as the capacity of women to make decisions/ choices inside the family unit with respect to their spouses (Anderson and Eswaran, 2009). Empowerment brings control (political, financial or social) for women, and such power fortifies women's financial and social position (Soroushmehr et al., 2012; Swanson and Timothy, 2012). When it comes to the business environment in Serbia, the above-mentioned variables are related to the question "How do you see the business environment in Serbia?". This study has shown that it contains a series of unfavorable conditions for the development of women's entrepreneurship, as entrepreneurs often perceive it as an unsupportive environment for entrepreneurship. In her oft-cited article on measuring WE, Kabeer (1999) suggested that a key element of empowerment is the "ability to make choices." Using various resources with an abundance of valuable information regarding this phenomenon is one of the key approaches. This approach was of priceless help for these women to find the best way to define their "empowerment" in the field of rural tourism in Serbia. We can also mention the following: the effects of empowerment are manifold (Datta and Gailey, 2012). The same authors showed that a strong woman has a "power" that is proportional to the amount of her self-confidence. Similar results have been found in our research, which points to the clear need for such associations. Moreover, the same authors observed WE in two directions: interpersonal and intrapersonal relations. The observed women, group members, showed a high degree of empowerment in both directions. Specifically, their research has shown that empowerment is most evident through economic security, the development of the entrepreneurial spirit, and the increase in the contribution of women in the family. All this affects the self-confidence and satisfaction of women. In both studies, the main limitation is the economic factor. However, in the case of our research, there is another aspect, which is the patriarchal arrangement of society (mostly dominating in rural areas). This means that the principle of empowerment should be systematically assessed.

The general impression that emerges from Table 3 is that SHG had a great influence on the WE, which is in line with studies of Thangamani and Muthuselvi (2013), Neetha (2020) and Anand et al. (2020). Support of SHG to women in developing countries ("the third world" countries by Scheyvens, 2000) results in their greater empowerment in all the studies that we analyzed. Although Serbia has significant cultural and religious characteristics in relation to Iran (Soroushmehr et al., 2012), Tanzania (Mrema, 2015), Malaysia (Kunjurman and Hussin, 2016), Indonesia (Tajeddini et al., 2017) and India (Thangamani and Muthuselvi, 2013; Neetha, 2020; Anand et al., 2020), it is far closer in its economic characteristics to previously mentioned countries than to the cases from the developed ones (Ateljevic, 2009; Bensemann and Hall, 2010). However, it differs significantly in one factor from the case of developing countries - the freedoms of women in Serbia are greater. Therefore, Serbia would be most appropriate for the case of European states (Nassani et al., 2019) with the cases where great support is needed from business environment, especially in the initial capital (in line with studies of Heilman and Chen, 2003; Bensemann and Hall, 2010). Considering the need for greater support of the business environment for tourism entrepreneurship of women in Serbia, our study is in line with Ateljevic's (2009) findings. The connection between these studies can be seen in the fact that Serbia, in its tourism strategies, often emphasizes the need to strengthen rural and regional development. There are also differences in urban and rural area business environment in both studies (like in Ateljevic, 2009). Finally, family-social factor (care for others) proved to be a strong motive of women for small business in rural tourism in Serbia. This is in line with studies of Bensemann and Hall (2010) and Tajeddini et al. (2017). Family values and relationships between members are strong, where women expect (emotional) support from their husbands and family in entrepreneurial activities. From the other side, the main difference between our study and analyzed studies is that old crafts and making handiwork are the main products of women in the studied area in Serbia compared with Neetha (2020), Rinaldi and Salerno (2019), Anand et al. (2020), and Bensemann and Hall (2010) in accommodation businesses, or with Tajeddini et al. (2017) in the small restaurants business. 


\section{Conclusion}

The strengthening of women's role in a society is one of the fundamental issues in the world. Using questionnaire-based research and analyzing their attitudes, we tried to get a clearer picture of how these women felt about their role and their empowerment in tourism development in the countryside they live in. We strongly believe that this study will be found useful in raising the awareness of women in the field of tourism by highlighting that the support they get in this closely-knit network and the possibility to express their creativity and skills can provide them with great opportunities to establish and develop their role in the tourism development in their small communities. This especially refers to the women in the less-advanced areas in developing countries because of the specific economic, psychological and social frames of these societies, such as Serbian.

As a final revealing, we set five points, which can help that these conditions be improved: (1) Women have a greater responsibility in the family; (2) They are facing a lack of funds; (3) They feel empowered as being part of an SHG; (4) The "best practice stakeholders" are in the areas of handmade products, like home-made products, souvenir production, or rural tourism; (5) The essential role of SHGs is providing information on loans and other financing conditions. Thus, the mission of WE in SHGs is that individuals from the group meet strong stakeholders, and the purpose of such networking is WE and starting their own businesses in rural surroundings. One is certain - women around the globe strive to become financially independent and to achieve a higher degree of freedom and independence within a family, which reflects in their influence and role in tourism industry. This affirmed the main hypothesis $\mathrm{HO}$ - Self-employment is an ultimate goal of women's empowerment. More exactly, by confirming hypotheses $\mathrm{H} 1$ (Women's empowerment depends on motive "care for others"), H2 (Women's empowerment depends on initial capital as part of the business environment), and H3 (Women's empowerment depends on the support of SHGs), research findings shed more light on the factors that affect the empowerment process to be more efficient and reliable with the ultimate effort for continuing and sustaining WE through tourism development in the future.

This research is important because it is one of the first empirical projects on WE, women's entrepreneurship in rural settings, along with the role of local partners and self-help groups in Serbia and this part of Europe. Moreover, Serbian society is currently going through an intensive period of adjusting to the new social and economic changes in the labor market, so WE and entrepreneurship play a significant role in the current processes of the society's transition, as well as in the development of local communities. This could be connected with the global trend of the support and encouragement of women in local businesses (such as tourism) in developing countries, especially in non-urban settings. The evident gap in this type of research should be upgraded and put forward in similar tourism studies that should be further developed.

The main limitation in the research and our suggestion for future research is to increase the sample size of female respondents so the examination of their attitudes and role in the travel business in their local settings might reach higher significance. Although 513 female respondents represent a significant sample for this type of analysis, the inclusion of more women in this and/or related research would further contribute to understanding the importance of their role in rural society and the progress they have made in the local economy. Moreover, their voices deserve to be heard in economic, political and academic circles. In addition, this would further contribute to the general tourism development of rural areas that still face a number of challenges (e.g. poor infrastructure, low level of education of the locals, remoteness from major market trends). The second issue that we would like to point out is the highly local character of our study (involved only one representative regional district in Serbia), so the future research should involve other rural areas in the country and from abroad (e.g. neighboring ex-communist countries or similar undeveloped countryside with active women's role in local entrepreneurship). Many neighboring countries went through the comparable turbulent economic and political regimes in the past few decades (e.g. Romania, Hungary, Bosnia and Herzegovina, Croatia) and women still face similar issues in rural areas: unsatisfactory economic transition, major demographic problems caused by mass-migration to urban centers and to abroad, neglected villages, insufficient involvement in decision-making at the 
local scale, the evident development gap between rural and urban areas, etc. Nevertheless, there are active women's associations with very similar initiatives like those ones presented in the study that can significantly contribute to the development of the local setting and become drivers of general economic growth through tourism. By including them, the entire research would have a greater sample of respondents and data would be more relevant and comprehensive for the chosen geographical area and similar developing societies.

Although there are limitations within this study that demand further research, certain benefits arise from our results. The most important practical implications of this paper are twofold: (1) the results of the research have shown that the tourism potential of rural areas can be enhanced through local tourism stakeholders' support; (2) women without professional interest or jobs in rural areas, especially in the areas where the population is dominated by men, have a chance to earn and to be economically more independent. This research can affect future studies to investigate other aspects of empowerment depending on the difference of regions, on one side, and also alternative opportunities for tourism and local development in less-advanced rural areas, on the other side. Taking into account the analysis on two "sensitive" aspects of contemporary social trends on the global scale - women's empowerment and countryside transformation/development, future studies should make an additional contribution to the cohesion of both fields and their important role in the travel industry in order to shed more light on these topics to the international audience. In this regard, a significant contribution can be made to these subjects that have been insufficiently elaborated even nowadays. In addition, the study may support future initiatives for the encouragement of these local/global processes through tourism.

\section{References}

Agarwal, B. (1997), "'Bargaining' and gender relations: within and beyond the household", Feminist Economics, Vol. 3 No. 1, pp. 1-51.

Al-Dajani, H. (2007), Women's Empowerment: A Comparison between Non-profit and For-Profit Approaches in Empowering Home-Based Women Producers, PhD thesis, University of Strathclyde, Glasgow.

Al-Dajani, H. and Marlow, S. (2013), "Empowerment and entrepreneurship: a theoretical framework", International Journal of Entrepreneurial Behaviour and Research, Vol. 19 No. 5, pp. 503-524, doi: 10.1108/ IJEBR-10-2011-0138.

Anand, P., Saxena, S., Martinez, R.G. and Dang, H.H. (2020), Can Women's Self-Help Groups Contribute to Sustainable Development? Evidence of Capability Changes from Northern India, Discussion paper series IZA DP No. 12940, 55 pages, Bonn.

Anderson, S. and Eswaran, M. (2009), "What determines female autonomy? Evidence from Bangladesh", Journal of Development Economics, Vol. 90 No. 2, pp. 179-191.

Ardrey, W.J., Pecotich, A. and Shultz, C.J. (2006), "Entrepreneurial women as catalysts for socioeconomic development in transitioning Cambodia, Laos and Vietnam", Consumption, Markets and Culture, Vol. 9 No. 4, pp. 277-300.

Ateljevic, J. (2009), "Tourism entrepreneurship and regional development: example from New Zealand", International Journal of Entrepreneurial Behaviour and Research, Vol. 15 No. 3, pp. 282-308.

Babbie, E. (1986), The Practice of Social Research, 4th ed., Wadsworth, Belmont, CA.

Bagozzi, R.P. (1981), "Evaluating structural equation models with unobservable variables and measurement error: a comment”, Journal of Marketing Research, Vol. 18 No. 3, pp. 375-381.

Baikuntha, A.P. and Elizabeth, H.A. (2013), "Homestays as an alternative tourism product for sustainable community development: a case study of women- managed tourism product in rural Nepal", Tourism Planning and Development, Vol. 10 No. 4, pp. 367-387.

Batliwala, S. (1994), "The meaning of women's empowerment: new concepts from action”, in Sen, G., Germain, A. and Chen, L. (Eds), Population Policies Reconsidered: Health, Empowerment and Rights, Harvard University Press, Cambridge, MA.

Bensemann, J. and Hall, C.M. (2010), "Copreneurship in rural tourism: exploring women's experiences", International Journal of Gender and Entrepreneurship, Vol. 2 No. 3, pp. 228-244. 
Branzei, O. (2012), "Social change agency under adversity: how relational processes (re)produce hope in hopeless settings", in Golden-Biddle, K. and Dutton, J. (Eds), Using a Positive Lens to Explore Social Change in Organizations: Building a Theoretical and Research Foundation, Routledge, London, pp. 21-47.

Buhalis, D. (2000), "Marketing the competitive destination of the future", Tourism Management, Vol. 21 No. 1, pp. 97-116.

Byrd, E.T. (2007), "Stakeholders in sustainable tourism development and their roles: applying stakeholder theory to sustainable tourism development", Tourism Review, Vol. 62 No. 2, pp. 6-13.

Calás, M., Smircich, L. and Bourne, K.A. (2009), "Extending the boundaries: reframing 'entrepreneurship as social change' through feminist perspectives”, Academy of Management Review, Vol. 34 No. 3, pp. 552-569.

Charmes, J. (2012), "The informal economy worldwide: trends and characteristics", Margin, Journal of Applied Economic Research, Vol. 6 No. 2, pp. 103-132.

Cinar, M.E. (2001), "Introduction", in Cinar, M.E. (Ed.), The Economics of Women and Work in the Middle East and North Africa, Elsevier Science B.V., Amsterdam, pp. 1-11.

Clarke, J. and Holt, R. (2010), "Reflective judgement: understanding entrepreneurship as ethical practice", Journal of Business Ethics, Vol. 94 No. 3, pp. 317-331.

Cole, S. (Ed.) (2018), Gender Equality and Tourism: Beyond Empowerment, CABI, Wallingford.

Cooper, C., Scott, N. and Baggio, R. (2009), "Network position and perceptions of destination stakeholder importance", An International Journal of, Tourism and Hospitality Research, Vol. 20 No. 1, pp. 33-45.

Cornwall, A. (2003), "Whose voices? Whose choices? Reflections on gender and participatory development", World Development, Vol. 31 No. 8, pp. 1325-1342.

Datta, P.B. and Gailey, R. (2012), "Empowering women through social entrepreneurship: case study of a women's cooperative in India", Entrepreneurship Theory and Practice, Vol. 36 No. 3, pp. 569-587.

De Bruin, A., Brush, C.G. and Welter, F. (2006), "Introduction to the Special Issue: towards building cumulative knowledge on women's entrepreneurship", Entrepreneurship Theory and Practice, Vol. 30 No. 5, pp. 585-593.

de Groot, J., Mohlakoana, N., Knox, A. and Bressers, H. (2017), "Fuelling women's empowerment? An exploration of the linkages between gender, entrepreneurship and access to energy in the informal food sector", Energy Research and Social Science, Vol. 28, pp. 86-97.

Decrop, A. (2004), "Trustworthiness in qualitative tourism research", in Phillimore, J. and Goodson, L. (Eds), Qualitative Research in Tourism: Ontologies, Epistemologies and Methodologies, Routledge, London, pp. 156-169.

Demirović, D., Košić, K., Surd, V., Žunić, L. and Syromiatnikova, Y. (2017), "Application of tourism destination competitiveness model on rural destinations", Journal of the Geographical Institute 'Jovan Cvijić' SASA, Vol. 67 No. 3, pp. 279-295.

Dredge, D. (1999), "Destination place planning and design”, Annals of Tourism Research, Vol. 26 No. 4 , pp. 772-791.

Ferguson, L. (2011), "Promoting gender equality and empowering women? Tourism and the third Millennium Development Goal”, Current Issues in Tourism, Vol. 14 No. 3, pp. 235-249.

Floro, M.S. (1995), "Economic restructuring, gender and the allocation of time", World Development, Vol. 23 No. 11, pp. 1913-1929.

Godwyn, M. (2009), “'This Place Makes Me Proud to be a Woman': theoretical explanations for success in entrepreneurship education for low-income women", Research in Social Stratification and Mobility, Vol. 27 No. 1 , pp. 50-64.

Gossling, S., Hall, C.M. and Weaver, D.B. (Eds) (2009), Sustainable Tourism Futures: Perspective on Systems, Restructuring and Innovations, Routledge, Abingdon.

Hair, J., Black, W., Babin, B., Anderson, R. and Tatham, R. (2006), Multivariate Data Analysis, 6th ed., Prentice Hall, Upper Saddle River, NJ.

Hania, U., Rachmaniaa, I.N., Setyaningsih, S. and Putri, R.C. (2012), "Patterns of Indonesian women entrepreneurship", Procedia Economics and Finance, Vol. 4, pp. 274-285. 
Hashemi, S.M., Schuler, S.R. and Riley, A.P. (1996), "Rural credit programs and women's empowerment in Bangladesh", World Development, Vol. 24 No. 4, pp. 635-653.

Haugh, H.M. and Talwar, A. (2016), "Linking social entrepreneurship and social change: the mediating role of empowerment”, Journal of Business Ethics, Vol. 133 No. 2016, pp. 643-658, doi: 10.1007/s10551-0142449-4.

Heilman, E.M. and Chen, J.J. (2003), "Entrepreneurship as a solution: the allure of self-employment for women and minorities", Human Resource Management Review, Vol. 13 No. 2, pp. 347-364.

Huo, Y. and Miller, D. (2007), "Satisfaction measurement of small tourism sector (museum): Samoa", Asia Pacific Journal of Tourism Research, Vol. 12 No. 2, pp. 103-117.

Jain, A.K. and Joy, A. (1997), "Money matters: an exploratory study of the socio-cultural context of consumption, saving, and investment patterns", Journal of Economic Psychology, Vol. 18 No. 6, pp. 649-675.

Jamali, D. (2009), "Constraints and opportunities facing women entrepreneurs in developing countries", Gender in Management, Vol. 24 No. 4, pp. 232-251.

Jarić, I. (2006), "Rekonfiguracija hegemonih modela (muških i ženskih) rodnih uloga u procesu transformacije srpskog društva", Filozofija I Društvo, Vol. 30 No. 2, pp. 175-190.

Kabeer, N. (1999), "Resources, agency, achievements: reflections on the measurement of women's empowerment", Development and Change, Vol. 30 No. 3, pp. 435-464.

Kabeer, N. (2005), "Is microfinance a 'magic bullet' for women's empowerment? Analysis of findings from South asia", Economic and Political Weekly, Vol. 40 Nos 44/45, pp. 4709-4718.

Kim, S., Stylidis, D. and Oh, M. (2019), "Is perception of destination image stable or does it fluctuate? A measurement of three points in time", International Journal of Tourism Research, Vol. 21 No. 4, pp. 447-461.

Kimbu, A.N. and Ngoasong, M.Z. (2016), "Women as vectors of social entrepreneurship", Annals of Tourism Research, Vol. 60, pp. 63-79.

Kline, C., Duffy, L. and Clark, D. (2018), "Fostering tourism and entrepreneurship in fringe communities: unpacking stakeholder perceptions towards entrepreneurial climate", Tourism and Hospitality Research. doi: 10.1177/1467358418781443.

Kolin, M. and Čičkarić, I. (2010), "Rodne nejednakosti u zapošljavanju, upravljanju i odlučivanju", Stanovništvo, Vol. 48 No. 1, pp. 103-124.

Kunjurman, V. and Hussin, R. (2016), "Women participation in ecotourism development: are they empowered", World Applied Sciences Journal, Vol. 34 No. 12, pp. 1652-1658.

Markantoni, M. and van Hoven, B. (2012), "Bringing 'invisible' side activities to light. A case study of rural female entrepreneurs in the Veenkoloniën, The Netherlands", Journal of Rural Studies, Vol. 28 No. 4, pp. 507-516.

Moser, C. (1989), "Gender planning in the third world: meeting practical and strategic needs", World Development, Vol. 17 No. 11, pp. 1799-1825.

Mrema, A.A. (2015), "Tourism and women empowerment in monduli district, arusha-Tanzania", African Journal of Hospitality, Tourism and Leisure, Vol. 4 No. 2, pp. 1-14.

Narayan, D. (Ed.) (2002), Empowerment and Poverty Reduction: A Sourcebook, World Bank Publications, WA, DC.

Nassani, A.A., Aldakhil, A.M., Abro, M.M.Q., Islam, T. and Zaman, K. (2019), "The impact of tourism and finance on women empowerment”, Journal of Policy Modeling, Vol. 41 No. 2, pp. 234-254.

Neetha, N. (2020), "Empowered or entangled: agency and choice in women employment in India", South Asian Survey, Vol. 27 No. 2, pp. 98-116.

Nelder, J.A. and Wedderburn, R.W.M. (1972), "Generalised linear models", Journal of the Royal Statistical Society A, Vol. 135, pp. 370-384.

Orser, B.J., Riding, A.L. and Manley, K. (2006), "Women entrepreneurs and financial capital", Entrepreneurship Theory and Practice, Vol. 30 No. 5, pp. 643-665.

Osirim, M.J. (2001), "Making good on commitments to grassroots women: NGO's and empowerment for women in contemporary Zimbabwe", Women's Studies International Forum, Vol. 24 No. 2, pp. 167-180. 
Peeters, L.W. and Ateljevic, I. (2009), "Women empowerment entrepreneurship nexus in tourism: processes of social innovation", in Ateljevic, J. and Page, S.J. (Eds), Tourism and Entrepreneurship, Routledge, London, pp. 75-89.

Petrović, M.D., Gelbman, A., Demirović, D., Gagić, S. and Vuković, D. (2017), "The examination of the residents' activities and dedication to the local community - an agritourism access to the subject", Journal of the Geographical Institute 'Jovan Cvijić' SASA, Vol. 67 No. 1, pp. 37-52.

Petrović, M.D., Vujko, A., Gajić, T., Vuković, D.B., Radovanović, M., Jovanović, J.M. and Vuković, N. (2018), "Tourism as an approach to sustainable rural development in post-socialist countries: a comparative study of Serbia and Slovenia", Sustainability, Vol. 10 No. 54, pp. 2-14.

Phillimore, J. and Goodson, L. (2004), "Progress in qualitative research in tourism: epistemology, ontology and methodology", in Phillimore, J. and Goodson, L. (Eds), Qualitative Research in Tourism: Ontologies, Epistemologies and Methodologies, Routledge, London, pp. 21-23.

Presser, H. and Sen, G. (2003), Women's Empowerment and Demographic Processes: Moving beyond Cairo, Oxford University Press, Oxford.

Ramanathan, M. (2004), "Women and empowerment: shri mahila griha udyog lijjat papad", Economic and Political Weekly, Vol. 39 No. 17, pp. 1689-1697.

Rao, S. (2011), "Work and empowerment: women and agriculture in South India", The Journal of Development Studies, Vol. 47 No. 2, pp. 294-315.

Rinaldi, A. and Salerno, I. (2019), "The tourism gender gap and its potential impact on the development of the emerging countries", Quality and Quantity, Vol. 54, pp. 1465-1477.

Rindova, V., Barry, D. and Ketchen, D.J. (2009), "Entrepreneuring as emancipation", Academy of Management Review, Vol. 34 No. 30, pp. 477-491.

Scheyvens, R. (2000), "Promoting women's empowerment through involvement in ecotourism: experiences from the Third World", Journal of Sustainable Tourism, Vol. 8 No. 3, pp. 232-249.

Scheyvens, R. and Biddulph, R. (2018), "Inclusive tourism development", Tourism Geographies, Vol. 20 No. 4, pp. 589-609.

Schuler, S.R. and Hashemi, S.M. (1993), Defining and Studying Empowerment of Women: A Research Note from Bangladesh, John Snow, JSI Research and Training Institute, Boston, MA.

Scott, L., Dolan, C., Johnstone-Louis, M., Sugden, K. and Wu, M. (2012), "Enterprise and inequality: a study of Avon in South Africa", Entrepreneurship Theory and Practice, Vol. 36 No. 3, pp. 543-568.

Seguino, S. (2000), "Gender inequality and economic growth: a cross-country analysis", World Development, Vol. 28 No. 7 , pp. 1211-1230.

Shams, S.M.R. (2016), "Branding destination image: a stakeholder causal scope analysis for internationalisation of destinations", Tourism Planning and Development, Vol. 13 No. 2, pp. 140-153.

Shams, S.M.R. (2017), "Transnational education and total quality management: a stakeholder-centred model", Journal of Management Development, Vol. 36 No. 3, pp. 376-389.

Soroushmehr, H., Kalantari, K., Fami, H.S. and Sarani, V. (2012), "Investigation of self-help groups (SHGs) effect on rural women empowerment (Hamedan county, Iran)", Journal of Agricultural Science, Vol. 4 No. 1, pp. 1-11.

Steyaert, C. (2007), "'Entrepreneuring' as a conceptual attractor? A review of process theories in 20 years of entrepreneurship studies", Entrepreneurship and Regional Development, Vol. 19 No. 6, pp. 453-477.

Stumpf, P., Vojtko, V. and Janecek, P. (2020), "Do European tourists intend to revisit the same countries? Effect of satisfaction in European Union destinations", Scandinavian Journal of Hospitality and Tourism, Vol. 20 No. 4, pp. 398-417.

Sudhakar Reddy, S., Galab, S. and Padmanabha Rao, P. (2003), "Trends and determinants of poverty: 1973-74 to 1999-2000", Economic and Political Weekly, Vol. 38 Nos 12/13, pp. 1262-1273.

Swanson, K.K. and Timothy, D.J. (2012), "Souvenirs: icons of meaning, commercialization and commoditization", Tourism Management, Vol. 33 No. 3, pp. 489-499.

Swart, M.P. and Roodt, G. (2015), "Market segmentation variables as moderators in the prediction of business tourist retention", Serv Bus, Vol. 9, pp. 491-513. 
Tajeddini, K., Ratten, V. and Denisa, M. (2017), "Female tourism entrepreneurs in Bali, Indonesia", Journal of Hospitality and Tourism Management, Vol. 31, pp. 52-58.

Thangamani, S. and Muthuselvi, S. (2013), "A study on women empowerment through self- help groups with special reference to mettupalay", IOSR Journal of Business and Management, Vol. 8 No. 6, pp. 17-24.

Timothy, D.J. (2007), "Empowerment and stakeholder participation in tourism destination communities", in Church, A. and Coles, T. (Eds), Tourism, Power and Space (199-216), Routledge, London.

Veal, A.J. (Ed.) (2017), Research Methods for Leisure and Tourism, Pearson, London.

Vujko, A., Penić, M. and Gajić, T. (2018), "The condition of the rural hospitality enterprises in rural tourism of Serbia”, Revista de la Facultad de Agronomia, Vol. 117 No. 1, pp. 53-60.

Vujko, A., Tretiakova, T.N., Petrović, M.D., Radovanović, M., Gajić, T. and Vuković, D. (2019), “Women’s empowerment through self-employment in tourism", Annals of Tourism Research, Vol. 76, pp. 328-330.

Vukovic, D., Maiti, M., Vujko, A. and Shams, R. (2019), "Residents' perceptions of wine tourism on the rural destinations development”, British Food Journal, Vol. 122 No. 8, pp. 2739-2753.

Waligo, V., Clarke, J. and Hawkins, R. (2015), "Embedding stakeholders in sustainable tourism strategies", Annals of Tourism Research, Vol. 55, pp. 90-93.

World Tourism Organization (UNWTO) (2011), The Global Report on Women in Tourism 2010, Madrid, available at: www.UNWTO.org.

\section{Further reading}

Boddy, C.R. (2016), "Sample size for qualitative research", Qualitative Market Research, Vol. 19 No. 4, pp. $426-432$.

Creswell, J.W. (1998), Qualitative Inquiry and Research Design. Choosing Among Five Traditions, Sage, Thousand Oaks, CA.

Eisenhardt, K.M. and Graebner, M.E. (2007), "Theory building from cases: opportunities and challenges", Academy of Management Journal, Vol. 50 No. 1, pp. 25-32.

Marshall, B., Cardon, P., Poddar, A. and Fontenot, R. (2013), "Does sample size matter in qualitative research?: a review of qualitative interviews in IS research", Journal of Computer Information Systems, Vol. 54 No. 1, pp. 11-22.

Sandelowski, M. (1995), "Sample size in qualitative research", Research in Nursing and Health, Vol. 18 No. 2 , pp. 179-183.

\section{Author affiliations}

Darko B. Vukovic is based at the Department of Credit and Finance, Faculty of Economics, RUDN University, Moskva, Russia and Regional Geography, Geografski institut Jovan Cvijic Srpske akademije nauka i umetnosti, Beograd, Serbia.

Marko Petrovic is based at the Geografski institut Jovan Cvijic Srpske akademije nauka i umetnosti, Beograd, Serbia and Institute of Sports, Tourism and Service, South Ural State University National Research University, Chelabinsk, Russia.

Moinak Maiti is based at the Department of Finance, National Research University Higher School of Economics, St Peterburg, Russia.

Aleksandra Vujko is based at the University of Business Studies, Faculty of Tourism and Hotel Management, Banja Luka, Republic of Srpska and European University, Faculty of European Business and Marketing, Belgrade, Serbia.

\section{About the authors}

Darko B. Vukovic, (corresponding author) is Professor at Finance and credit department, Faculty of Economics, People's Friendship University of Russia (RUDN University), in Moscow, Russia. He is engaged on international master program, subjects: Financial markets and institutions and Financial Risk Management. Since 2008, dr Darko Vukovic works at Geographical Institute "Jovan Cvijic" of the Serbian Academy of Sciences and Arts, at position Chief of Department of regional economics and economic geography. Darko B. Vukovic is the corresponding author and can be contacted at: vdarko@hotmail.rs 
Marko Petrović, PhD, is Research Associate at Social Geography Department of the Geographical Institute "Jovan Cvijić," Serbian Academy of Sciences and Arts in Belgrade (Serbia) and visiting professor at the Institute of Sports, Tourism and Service, South Ural State University in Chelyabinsk (Russia). His research is centered upon rural and peri-urban development, rural economy, agritourism, tourism's impact assessment, community-based economy planning, spatial aspects of tourism and geotourism. Dr. Petrović has authored more than 90 publications and he is a member of the numerous organizations and entities in the field of science and education in geography and tourism.

Moinak Maiti, PhD, is Associate Professor in the Department of Finance, National Research University-Higher School of Economics, Saint Petersburg, 194100, Russia. His research work received appreciation globally and invited to present his work at several notable platforms such as PEP Canada, World Bank, United Nations, Central Banks, SAS and Bloomberg. Several research grants from world renowned institutions such as PEP Canada, World Bank, United Nations, Central Banks and others are added to his account. His articles appear regularly at the several wellknown journals, book chapters and blogs. Beside an author, he is invited referee for several reputed publishing houses like Elsevier, Springer, Wiley, Emerald and others.

Aleksandra Vujko, PhD, currently works as a professor at Novi Sad Business School, and as a Senior Research Staff at the South Ural State University (SUSU) in Chelyabinsk (Russia). Also, she is Assistant Professor at the Faculty of Tourism and Hotel Management in Banja Luka, BiH. Her study area is Tourism Management, Rural Tourism, Sport and recreational Tourism, Quality Services, HR in Tourism and Tourism and Hotel Management. She has written many international academic journal articles and conference papers.

For instructions on how to order reprints of this article, please visit our website: www.emeraldgrouppublishing.com/licensing/reprints.htm

Or contact us for further details: permissions@emeraldinsight.com 